\title{
Crohn's disease in two married couples
}

\author{
J M RHODES, T MARSHALL, J D HAMER, AND R N ALLAN \\ From the Queen Elizabeth and General Hospitals, Birmingham and The Department of Social Medicine, \\ University of Birmingham
}

SUMmaRY Only two examples of married couples where both partners have developed Crohn's disease have been reported previously from the United Kingdom. We describe two further examples; one where the index patient had developed Crohn's disease before marriage, and the spouse subsequently developed Crohn's disease and a second example in which both spouses developed Crohn's disease after marriage.

If Crohn's disease is caused by an infective agent then the spouses of patients might be at particular risk of contracting the disease. There are, however, only three reported instances of Crohn's disease developing after marriage in the spouse of a patient; two couples from the $\mathrm{UK}^{12}$ and one from the USA. $^{3}$ If a prevalence of Crohn's disease of 35/ 100000 is assumed then the chance of Crohn's disease occurring in an unrelated spouse is (35/ $100000)^{2}-$ that is, about 1 in 8 million. As there are just over 12 million married couples in England and Wales (1981 census) only 1.5 couples with Crohn's disease would be expected to have occurred by chance in England and Wales. ${ }^{1}$

\section{Case Reports (Table)}

\section{COUPLE A}

Mr B G, born in 1949, caucasian, presented in May 1979 with a perianal abscess and fistula. Granulomata were present in tissue biopsied from the wall of the fistula which closed spontaneously. He returned in 1981 with diarrhoea when barium enema examination showed typical changes of Crohn's disease with relative rectal sparing. Rectal biopsy showed marked inflammatory change and several granulomata were identified. He responded well to oral metronidazole and sulphasalazine with steroid enemata. He remains well.

Mrs K G, born 1951, causasian, married B G in 1971. She presented in November 1979 with colicky

Address for correspondence: Dr J. M. Rhodes, Queen Elizabeth Hospital, Edgbaston, Birmingham B15 2TJ.

Received for publication 12 November 1984 lower abdominal pain, abdominal distension, and weight loss. She was initially treated symptomatically but in June 1980 was found to have an iron deficient anaemia (haemoglobin $11.2 \mathrm{~g} / \mathrm{dl}, \mathrm{MCV} 71$ fl). Barium meal and barium enema examinations were normal. A laparotomy in August 1981 for severe abdominal pain showed Crohn's disease in the distal ileum and caecum and an associated abscess. The distal ileum and caecum were resected. Histopathological examination showed a thickened and ulcerated ileum with numerous granulomata. She remains well.

COUPLE B

Mr J A, born in 1928, caucasian, experienced episodic diarrhoea from 1948. He presented in 1960 with a sinus close to the left iliac crest which drained intermittently for two years. He was referred in 1975 with persistent diarrhoea. Sigmoidoscopy showed a mild distal proctitis and the rectal biopsy contained granulomata. The barium enema examination showed the appearances of colonic Crohn's disease with several 'skip' lesions and involvement of the distal ileum. He responded well to steroid enemata and sulphasalazine. The abdominal wall sinuses discharge occasionally but his general health remains good.

Mrs A A, born 1931, caucasian, married J A in 1952. She presented in 1978 with a five year history of diarrhoea. Sigmoidoscopy appearance was normal but the rectal biopsy contained granulomata. A barium enema showed typical appearances of Crohn's disease affecting the upper rectum, sigmoid and left colon. She responded well initially to oral 
Table Time table of events in two couples with Crohn's disease

\begin{tabular}{|c|c|c|c|c|c|}
\hline & \multirow[b]{2}{*}{ Date of birth } & \multirow[b]{2}{*}{ Sex } & \multirow[b]{2}{*}{ Onset of Symptoms } & \multicolumn{2}{|c|}{ Diagnosis } \\
\hline & & & & Date & Primary site of disease \\
\hline \multicolumn{6}{|c|}{ Couple A Married 1971} \\
\hline B G & 1949 & $\mathbf{M}$ & May 1979 & 1979 & Colon with perianal disease \\
\hline K G & 1951 & $\mathbf{F}$ & Nov 1979 & 1981 & Distal ileum and caecum \\
\hline \multicolumn{6}{|c|}{ Couple B Married 1952} \\
\hline J A & 1928 & $\mathbf{M}$ & 1948 & 1960 & Distal ileum and colon \\
\hline A A & 1931 & $\mathbf{F}$ & 1973 & 1978 & Colon \\
\hline
\end{tabular}

sulphasalazine and subsequently received oral metronidazole for a relapse. She remains well.

\section{Discussion}

Crohn's disease developing after marriage in a spouse of a patient with established disease seems to be a rare event. These two examples bring the reported number of couples with Crohn's disease in England and Wales to four.

Whorwell and his colleagues suggest that the prevalence of Crohn's disease is 35.02/100 000. ${ }^{1}$ There are 12.1 million married couples in England and Wales (1981 census) so that the chances of finding four or more married couples with the disease in England and Wales as predicted from a Poisson distribution would be $p=0.066$ and the identification of one further example would reach statistical significance ( $p$ for five or more couples = $0 \cdot 019$ ). Mayberry and his colleagues have reported a prevalence of 55.7/100 000 in Cardiff. ${ }^{4}$ If this prevalence rate is used then the expectation of 3.72 spouses developing Crohn's disease by chance is close to the reported total of four examples.

In both these examples the first affected partner had a persistent discharge from a sinus or fistula and it is difficult to persuade them that their disease is not infectious. Unless further examples remain unreported, however, Crohn's disease seems to occur about as frequently in the spouse of a patient as would be expected by chance.

We should like to thank Mr D Campbell and Dr R Cockel for permission to include patients under their care.

\section{References}

1 Whorwell PJ, Eade OE, Hossenbocus A, Bamforth J. Crohn's disease in a husband and wife. Lancet 1978; 2: 186-7.

2 Whorwell PJ, Hodges JR, Bamforth J, Wright R. Crohn's disease in a husband and wife. Lancet 1981; 1: 334.

3 Zetzel L. Crohn's disease in a husband and wife. Lancet 1978; 2: 583.

4 Mayberry JF, Rhodes J, Newcombe RG. Familial prevalence of inflammatory bowel disease in relatives of patients with Crohn's disease. Br Med J 1980; 1: 84. 